\title{
SHOULD WE PATENT IT OR KEEP IT A SECRET? \\ THE MODERATING ROLE OF PROACTIVE ORIENTATION IN FAMILY VERSUS NON-FAMILY SMES
}

\begin{abstract}
We investigate how family and non-family small-and-medium size enterprises (SMEs) differ in their preference for patenting over secrecy as a means to protect value of intellectual property, and how proactive orientation moderates this relationship. Because secrecy carries more risks for spillover than patenting, we propose and provide evidence to suggest that family SMEs are more likely to use patents than secrecy relative to nonfamily SMEs as a mechanism to protect value. However, proactive orientation can weaken this relationship, since SMEs with a proactive orientation will avoid the disclosure of information required for patenting. Using a sample of 300 SMEs from four countries in the wine industry, we find support for our hypotheses and contribute to both the intellectual property (IP) and SME literatures by explaining how family SMEs relative to non-family SMEs protect the value of IP.
\end{abstract}

\section{Key words}

Family firms; proactive orientation; secrecy; SMEs, patents 


\section{SHOULD WE PATENT IT OR KEEP IT A SECRET? THE MODERATING ROLE OF PROACTIVE ORIENTATION IN FAMILY VERSUS NON-FAMILY SMES}

\section{Introduction}

Literature on intellectual property (IP) rights has revealed that secrecy, i.e. intentionally withholding information on intellectual property from those external to the firm (Bos et al., 2015), is a more prevalent method of firms' protecting the value of IP than patenting (Alcácer et al., 2017; Cohen et al., 2002; Hall et al., 2014). However, although a number of contingency factors have been considered in the patenting literature such as country differences (Cohen et al., 2002; Crowley, 2004), industry differences (Alcácer et al., 2017) or innovation types (Arundel, 2001), a major focus has been placed on large firms. Only a few studies have sought to understand when small-and-medium size enterprises (SMEs) would prefer to use secrecy as a means of IP value protection over patenting (Gan et al., 2013; Leiponen and Byma, 2009). Thus, our understanding of the factors that motivate SMEs to select patents rather than secrecy or visa versa is limited.

Furthermore, we know even less about the impact SMEs' firm-level factors have upon their preference for protecting IP with patents or secrecy than we do on macrofactors. For example, such a preference may be influenced by whether SMEs are family owned-or-controlled or not (Howorth et al., 2010). Recent work has examined how family involvement, as an informal mechanisms or institution, moderates the relationship between the strength of formal IP in a country and firms' $R \& D$ resource allocation decisions (Brinkerink and Rondi, 2020). However, R\&D decisions are related to SMEs' inputs to the innovation process and not the mechanism they select to protect the IP once it has been developed. Hence, more research is needed to understand the differences between SMEs that are family firms and those that are non-family firms in their preferences for patenting or secrecy as a means to protect their IP.

A second firm level factor that may be relevant to SMEs' choice between patents and secrecy as a mechanism to protect IP is their proactive orientations. The SME literature has differentiated between family firms and their non-family counterparts based on their entrepreneurial behaviour (Howorth et al., 2010, 2014; Melin et al., 2014) and 
one element of entrepreneurial behavior is proactive orientation (De Massis et al., 2014; Naldi et al., 2007). However prior research has not analysed the impact of a proactive orientation upon the choice between patenting and secrecy in family firms. Thus, we integrate the research that has been conducted on the different means of value protection of IP and the SME literature to develop theory to explain why family firms (vs. nonfamily firms) are more likely to prefer patenting over secrecy to protect and capture value from IP. We also consider how proactive orientation moderates that relationship. For our purposes we limit our theorising to SMEs and posit that understanding the conditions under which one method or another is preferred is important for SMEs in general and family firms in particular, in order to avoid failures in value protection and capture from IP.

We chose the wine industry as our research context for two reasons. First, secrecy can be and is a widely acknowledged means of value protection and capture for core products in this industry for both the wine-making "recipes" or proprietary blends and production methods. Studies have largely overlooked the fact that SME managers in the wine industry can anticipate and react to a changing competitive environment by either safeguarding their 'exclusive' and 'secret' recipes for winemaking by keeping them secret or by applying for patents. Second, the wine industry is dominated by SMEs most of which are family firms and controlled by family members (Cordano et al., 2010; Thach, 2015; Williams and Spielmann, 2019). Furthermore, wine experts distinguish between two distinct wine producing locations: the Old World (where wine has been produced for centuries such as in France and Italy) and the New World (where winemaking is relatively new, such as Canada, UK, USA and Denmark) (Spielman et al., 2019). This is especially important, because prior literature suggests that the use of secrecy is highly countryspecific (Cohen et al., 2002; Crowley, 2004) and countries have been associated with three different levels in terms of legal enforcement of IP rights (La Porta et al., 1998). Thus, we chose to include wineries and vineyards from four countries in the study to control for country-level effects. Consequently, we conducted a survey with 300 wine SMEs in Italy, France, the United States, and Denmark. These countries have different legal environments in terms of the strength of their legal system in enforcing IP, e.g., Denmark has the strongest legal system, followed by the US, in turn followed by France 
and Italy (La Porta et al., 1998). This selection of countries enhances the generalisability of the results across different legal environments.

Our study contributes to both the IP and SME literatures by explaining how SMEs protect and capture value from IP. Value capturing studies in the innovation literature on IP have primarily focused on country, industry, and innovation type, and have overlooked the impact of firm-level characteristics upon the choice of patenting relative to secrecy as a means of value protect and capture from IP. The SME literature has had limited research on value protection and capture, in particular preferences for patenting versus secrecy in family relative to none-family SMEs. This article addresses these important gaps in the literature by considering the importance of two firm-level characteristics on the choice of patenting versus secrecy: family SMEs relative to non-family SMEs and the SMEs' proactive orientation. Our findings suggest that SME type in terms of family versus nonfamily, and the SMEs' proactive orientation both influence their choice of value protection and capture mechanism, i.e. when they prefer patents relative to secrecy.

In the sections below, we first briefly review the relevant literature on IP rights and the mechanisms used to protect and capture value from IP. We then discuss the SME literature on family firms to develop theory and propose the direct effect of family firms relative to non-family firms on the preference for using patenting instead of secrecy as a means of value protection and capture. We follow this by developing theory to propose how proactive orientation moderates this relationship. Next, we describe our study and report our findings. We conclude by discussing our contribution to the literature, the study's limitations, and future research directions.

\section{Theoretical background and hypotheses development}

The choice between secrecy and patenting

Recent innovation research suggests that innovative products and practices are expected to be safeguarded through different strategies and mechanisms (Bos et al., 2015), including secrecy and patenting. Patenting and secrecy are considered strategies that proactive firms use to protect their knowledge (Sofka et al., 2018; Veugelers and Schneider, 2018). In particular, the IP rights research suggests that firm managers explicitly consider the risk and reward probabilities associated with the choice of secrecy in order to maximize their expected utility (Kahneman and Lovallo, 1993), and also weigh 
the risks associated with secrecy against the limitations of patent protection (Denicolò and Franzoni, 2004). Most businesses keep and protect secrets, spanning all functional areas of the business (Crittenden et al., 2015), because secrecy may limit external access to internal knowledge and capabilities and help retain advantages over competitors and other parties over time. Relatedly, innovation research has paid substantial attention to patenting (Holgersson, 2013) in the context of SMEs, suggesting that formal IP rights in the form of patenting may signal the quality of the firm and their conformity with highlevel industry (technical) standards (Gick, 2008), and has also argued that SMEs find secrecy more useful for protecting their IP than patenting (Leiponen and Byma, 2009).

While a few studies in the innovation literature have looked at when SMEs choose secrecy over patenting or vice versa (Gan et al., 2013; Leiponen and Byma, 2009), there have been contradictory findings regarding the relationship between family firms and the propensity to patent (Bannò, 2016; Tognazzo et al., 2013). Patenting requires the "disclosure of the knowledge associated with the innovation and prevents imitation through the threat of punishment in court" (Sofka et al., 2018: 559), but family firms may be unwilling to disclose information associated with their innovations. For example, family firms in the wine industry often have family recipes that have been handed down from generation to generation, which family members do not want to disclose publicly for fear other firms will imitate their recipe (Woodfield and Husted, 2017). Furthermore, according to the behavioural agency perspective, family firms must weigh the benefits of their investment decisions in terms of prospective financial wealth such as sustained economic gains, isolating mechanisms, and quality signals against the costs of those investments in terms of potential losses of current socio-emotional wealth (Ardito et al., 2019). Socio-emotional wealth refers to non-financial aspects of the firm that help to meet the family's affective needs, such as their identity, the ability for the family to exercise influence, and the perpetuation of the family dynasty (Gómez-Mejía et al., 2007). The loss of socio-emotional wealth, due to the loss of a sense of control, can result in the diversion of resources and the disclosing of information by management, legal challenges for family members, and the need for specialized human capital to address the various issues between various stakeholders (Chirico et al., 2018).

On the other hand, secrecy has received less attention than patenting in the SME literature on family firms. Secrecy as a means of value protection is very different from 
patenting. For example, James et al. (2013: 1132) argued that protecting and capturing value using secrecy involves the "use of internal policies and procedures that restrict the flow of information both within and outside the organization". In their study of the relationship between ownership structure and voluntary disclosure of intellectual capital, Gan and colleagues (2013) found that family-owned firms strictly adhere to secrecy whenever possible by disclosing no more details than stipulated by law. Still, it is surprising how little SME research has considered the use of secrecy by family firms and when patenting is used instead of secrecy, given it is considered an important mechanism that firms use to maximize the portion of the value they capture from their IP.

The lack of discussion around when SMEs prefer patenting over secrecy and how proactive orientation influences this preference is surprising, because secrecy is closely associated with family dynamics that tend to characterise family firms (Kets de Vries, 1993; Ward, 1997). For this reason, some scholars have assumed that family firms demonstrate a major propensity towards secrecy (Casillas et al., 2011; Sharma and Manikutty, 2005), since the firm's ownership and leadership are typically passed down from generation to generation within the family, protecting the secret recipe of the family firm (Woodfield and Husted, 2017). However, this assumption remains relatively unexplored and the bases for this assumption have not been empirically tested. Thus, in this paper, we develop and test theory regarding family firms' preference for using patenting relative to secrecy to protect IP, and how a proactive orientation moderates this relationship.

\section{Family versus non-family SMEs}

Research acknowledges the influence of family involvement and participation in SME management and development (Basco, 2014; Howorth et al., 2010). While there is no widely accepted family firm definition, studies have revealed that family firms differ from non-family firms by the interconnected nature of family and business dynamics (Howorth et al., 2010; Intihar and Pollack, 2012). Most definitions for family firms have been based on either family ownership, management control by family members, or some combination of these two criteria with other related ones (Hernández-Linares et al., 2018; Hernández-Linares and López-Fernández, 2018). Whatever the measure used, studies defining SMEs as family firms suggest that members of a family in a SME have control 
over the decisions and resources that affect the firm in the long term and family members hold top management positions that enable them to influence and execute strategic choices (Howorth et al., 2010). The uniqueness of family firms is related to the amount of weight the founders and their families have in deciding the way the company operates and differentiates itself from other firms over time (Fletcher, 2002).

Agency theory and the resource-based view are two theories commonly used in family business research to explain different characteristics of family firms that are likely to affect innovation output (Matzler et al., 2015) and their entrepreneurial orientation (Hernández-Linares and López-Fernández, 2018). Particularly, literature has differentiated family SMEs from their non-family counterparts based on their entrepreneurial behaviour (Howorth et al., 2014; Melin et al., 2014). More specifically, research suggests that family firms are less entrepreneurial and less innovative since they have a long term orientation, tend to be more conservative, more risk-averse (Kraiczy et al., 2015; Naldi et al., 2007; Zahra, 2005), and less able to adapt to market changes (Lubatkin et al., 2007). Research also suggests that there is a negative relationship between family involvement and investments in R\&D (Block, 2012; Chen and Hsu, 2009). Nevertheless, there is no clear consensus, because other research considers the long term orientation of family firms as evidence of their longstanding commitment to innovation (Llach and Nordqvist, 2010; Nordqvist et al., 2008). However, it is also likely that the risk-aversiveness of family firms will also affect the choices family firms make on how to innovate and whether to protect the value of IP using patenting or secrecy.

The IP rights literature tells us that the primary risk associated with using secrecy rather than patents to protect IP is that the secret may spillover to competitors, who then can place the same product on the market (Hall et al., 2014). Because family firms tend to be risk-averse and secrecy typically carries more risks for spillover than patenting (Naldi et al., 2007; Zahra, 2005), we propose that family firms are more likely to use patents relative to secrecy as a mechanism to capture value. Because family firms are often more conservative and less willing to take risks than non-family firms, we posit that risk aversion may motivate them to protect the family's interest by patenting their products and processes in a way that can be protected by the legal system. We hypothesise that family firms are willing to incur the significant costs of patenting in order to retain control over their firms and protect their socio-emotional wealth (Block et al., 2013). 
In addition, in family firms, the majority of the equity is typically owned by family members and may have been in the family for generations (Llach and Nordqvist, 2010; Zahra et al., 2004). Under these conditions, even family members that are not responsible for day-to-day management of the firm are likely to see the business as their family's heritage, and believe that it is their responsibility to involve themselves in the decisions made by the firm (Basco, 2014). Family members that are involved in the management of the firm also often do not have a diversified financial portfolio or diversified human capital, both of which can foster risk aversion (Schmid et al., 2014). This tendency toward risk aversion may lead family members, managers and non-managers, to take actions on behalf of the firm to preserve the status quo and continue to do things as they have always been done them despite the potential for a stronger economic performance if changes were made (Gómez-Mejía et al., 2007). Thus, family managers are more likely than nonfamily managers to introduce management processes that help the firm to survive as a family firm across generations (Jell et al., 2015).

Alternatively, in the case of non-family firms, the agent-managers often have a more limited ownership stake and less personal affiliations with other equity owners (Casillas et al., 2011). As a result, while family members running a family firm can be expected to be more concerned about their family's ownership, identity, or socioeconomic wealth in the business and be less willing to take risks, managers of nonfamily firms may be more willing to take risks in the hopes of greater short-term profits (Jell et al., 2015), which is often linked to their compensation. Given that patents provide legal protection against rivals imitating the firm's products and processes and, thus, can be used as an isolating mechanism (Lippman and Rumelt, 2003), more conservative riskaverse family firms can be expected to choose patenting over secrecy more so than nonfamily firms. From these arguments, we propose that:

H1: Family SMEs (as compared to non-family SMEs) consider patenting a more effective means than secrecy for protecting and capturing value from intellectual property.

\section{Proactive orientation as a moderator}

Family firms' proactive behaviour can provide them with significant advantages relative to other firms in terms of their ability to pioneer practices that affect the 
perception of products or services by customers (Lieberman and Montgomery, 1988) and allow them to capture value (James et al., 2013). A proactive orientation "refers to an opportunity-seeking, forward-looking behaviour that incorporates acting on future needs and trends ahead of competitors, thereby actively entering new product/market spaces, creating first-mover advantages, and seeking market leadership positions" (Lomberg et al., 2017: 3). Furthermore, Miller (1983: 771) posited that firms that engage in productmarket innovation and undertake somewhat risky approaches may be the first to come up with 'proactive' innovations, thereby "beating competitors to the punch". Thus, a proactive orientation could motivate family firms to choose secrecy over patenting as a means of protecting their IP.

There is no consensus in the SME literature on the relationship between family firms relative to non-family firms and proactive orientation. While some authors claim that family firms are less entrepreneurial and innovative (Carney, 2005; Garcés-galdeano et al., 2016; Naldi et al., 2007), other streams of literature discuss that family firms may pursue more R\&D activities and be more innovative than non-family counterparts (Llach and Nordqvist, 2010; Nordqvist et al., 2008). De Massis and colleagues (2014) reviewed two literature streams related to the proactive orientation of family firms: the stewardship perspective, which recognises a proactive search for opportunities by family firms; and the agency theory perspective, which considers family firms as conservative and riskaverse, not devoted to the search of opportunities.

The literature arguing that family firms are more innovative than non-family ones relies mainly on their long-term orientation. As family firms tend to be long-term oriented, they dedicate resources for innovation in the short-term, thereby fostering entrepreneurship (Llach and Nordqvist, 2010). In doing so, they will seek to keep the business updated to market needs, reflecting a dynamic interplay, so that the family business can be passed from generation to generation (Llach and Nordqvist, 2010; Zahra et al., 2004) through a bounded intergenerational reciprocity process to share the accrued family value (Janjuha-Jivraj and Spence, 2009). Thus, the desire to create transgenerational value and long-lasting firms may encourage family firms to proactively invest in entrepreneurial activities (Chirico and Nordqvist, 2010; Zellweger and Sieger, 2012). 
Zahra and colleagues (2004) examined the importance of organizational culture in family vs. non-family firms and entrepreneurship. Using data from U.S. manufacturing companies, they found that there was a positive linear relationship between entrepreneurship and a long- versus short-term orientation. A long- versus short-term orientation had more impact upon entrepreneurship in family firms when compared with non-family firms. Hence, long-term oriented family firms may seek to be more proactive and entrepreneurial than non-family firms. In the same way, Casillas and colleagues (2011) found that when family members from the next generation are involved in running the family business, the entrepreneurial orientation is stronger. Chrisman and Patel (2012) showed that when family firms attach more importance to long-term family goals, they are more willing to make risky decisions. It follows then that if a family firm has a longterm orientation, it will be more entrepreneurial and proactive in its efforts to make shortterm investments that will affect its long-term viability, and that this will lead the managers to be less sensitive to the risks protected by patenting and more willing to protect and capture value through secrecy.

The effect of a proactive orientation might also be stronger in family firms than in non-family firms, because of the risk of losing socio-emotional wealth (Chrisman and Patel, 2012; Gómez-Mejía et al., 2007). Gómez-Mejía and his colleagues (2007) drew on the concept of socio-emotional wealth to explain the trade-off family firms make between risk aversion and a long-term orientation. Defining socio-emotional wealth as the nonfinancial aspects of the firm that meet the family's affective needs, they suggested that family firms will embrace risky decisions that preserve emotional ties even though those decisions decrease long-term economic wealth. Likewise, they suggest family firms will avoid risky decisions that reduce socio-emotional wealth even if those decisions may increase long-term economic wealth. While family firms are commonly risk averse, Gómez-Mejía and his colleagues (2007) argue that the situation might change when their socio-emotional wealth is threatened (Craig et al., 2014).

Although patenting might lead to some socio-emotional gains, these gains are unlikely to counterbalance the potential loss of control associated with patenting and family firms' aversion to possible socio-emotional wealth losses. The potential loss of control and socio-emotional wealth should lead to a lower propensity to patent, though there might be specific conditions that favor an alignment between multiple goals 
(Chirico et al., 2018). As a result of the commitment to protect their socio-emotional wealth, a strong proactive orientation is likely to attenuate the preference of family firms relative to non-family firms for patenting versus secrecy as an instrument to protect and capture value. This will allow them to avoid the disclosure of information required to receive patents.

Family firms may prefer privacy over patenting relative to non-family firms for other reasons (Envick et al., 2008), especially in the wine industry. In this industry proactive family firms may well have a set of closely guarded activities developed over generations, which include unpatented or unpatentable tacit knowledge around a product or production process, which the family firm may not want to reveal to others in the same industry. The IP literature has evidenced a high degree of cross-functionality in patent management in family firms that might imply secrecy provides a more effective protection for their inventions than patents (Jell et al., 2015). Furthermore, family firms in the wine-making industry may be more proactive in leading and implementing innovative wine-making practices or trying to unlock the secrets of new ways of producing, commercializing and enjoying wine (Hall et al., 2015; Jackson, 2017), because they seek to enhance and build on the heritage of their family firm.

Thus, we propose that the relationship between family firms and a preference for patenting over secrecy will be moderated by SMEs' proactive orientation. Specifically, we posit that increases in proactive orientation will make family firms (as compared to non-family firms) less likely to prefer patenting over secrecy. Thus, we propose that:

H2: The more proactive the SMEs' orientation, the weaker the relationship between family SMEs (as compared to non-family SMEs) and their preference for patenting relative to secrecy as a more effective means for protecting and capturing value from intellectual property.

\section{Methodology}

\section{Sample and Data Collection}

The wine industry represented the ideal research setting for our analysis, as the use of secrecy is common in this industry, where recipes and techniques can be kept as a secret (Vrontis and Paliwoda, 2008). We used survey data on 300 SMEs from four countries: the United States, Italy, Denmark and France. Since prior literature has shown 
great differences across countries in the use of secrecy (Cohen et al., 2002; Crowley, 2004), a multi-country study is likely to ensure greater generalisability of the findings. The four countries are also associated with three different levels in terms of law enforcement of IP rights. Scandinavia (i.e. Denmark) is considered in the top-tier in terms of law enforcement, followed by common law countries (i.e United States) and then by the French civil law countries (i.e. to which France and Italy belong) (La Porta et al., 1998). Therefore, by choosing these four countries we can rule out that our results depend on the level of law enforcement of IP in an individual country.

The survey was developed in English, and then translated into Italian, Danish, and French, and then back-translated into English. This procedure was done to avoid mistranslations and bias based on language errors. Furthermore, interviews in each country were conducted to support the back-translation process (Brislin, 1970; Chidlow et al., 2014). The process of gathering the data differed somewhat in each country to better consider the local conditions and based on learning. First, data was collected in the United States. A random stratified sample of 1,000 firms from four States (North Carolina, Virginia, Oregon, and California) was first mailed post cards and then called on the telephone to ask if they would participate in the study. From that population, approximately $20 \%$ of the firms were no longer in business, and only 77 wineries and vineyards agreed to participate in the study after multiple telephone calls. A link to an online questionnaire was sent to those willing participants. Twenty seven firms completing the questionnaire (response rate $=35 \%$ for those that agreed to participate), but only 25 were included in our analysis due to missing data.

Second, data was collected in Itally, where the survey was also administered through an online questionnaire. Due to the high number of wineries and vineyards in this country (over 92,000), the survey sample consisted of 800 firms in the 10 main winery consortia located in five main regions of Italy (Emilia Romagna, Lombardia, Sicilia, Toscana, and Veneto). From that sample, 246 firms completed the online survey (response rate $=30.75 \%$ ). However, only 137 of these had sufficient data to be included in our analysis.

Third, we collected data in Denmark, where the invitation to participate in the study was extended to all the wineries and vineyards (70 firms), which were members of the two national wine associations. The associations first contacted their member firms 
through e-mail. After some follow-up e-mails and phone calls by one of the co-authors, managers of 51 firms used the link they were sent to complete the online questionnaire (response rate $=72 \%$ ), although only 31 had complete data and could be used in this study.

Finally, in France, a random stratified sample of 500 firms were contacted by telephone and invited to participate in a telephone interview where the study questions would be asked and recorded. Telephone interviews were used instead of the online survey because of concerns that the firm managers would not participate unless the interviews were done in person. A professional market research firm was hired to conduct telephone interviews. In total, 107 wineries and vineyards agreed to participate in the study (21.4\% of those telephoned) and all of them completed the questionnaire and were used in this study.

Thus, in total, sample used in our analysis consists of 300 observations: 25 from the U.S., 137 from Italy, 31 from Denmark, and 107 from France. There are several reasons for the differences in response rates among the 4 countries we sampled. First, there was a certain amount of learning-by-doing, starting data collection in the US, followed by Italy, Denmark and France. Second, the US population of wineries have been oversampled for studies by US academics, while wineries in the other three countries have been comparatively less investigated. Third, Denmark is a small producer of wine relative to the other three countries. Furthermore, the Danish population is well known for their active participation in surveys for both their government and fellow academics.

To examine whether common method bias was an issue (Podsakoff et al., 2003), we conducted a principal component factor analysis of the survey items used in the study, which revealed the presence of eight distinct factors with eigenvalues greater than 1.0, rather than a single factor. The eight factors together accounted for $69 \%$ of the total variance; the first (largest) factor did not account for a majority of the variance (15\%). Thus, no general factor is apparent, suggesting that common method bias was not a problem in this study.

\section{Variables and Measures}

Dependent variable

The extent to which firms use patenting relative to secrecy is our dependent 
variable (Patenting/(Patenting+Secrecy)). Consistent with prior survey studies (Alcácer et al., 2017; Arundel, 2001), we captured the use of secrecy through the question: "To what extent were trade secrets effective for maintaining or increasing firm competitiveness of product and process innovations over the last three years?" Respondents assessed the use of secrecy on a 4-point Likert scale where 1 indicates "not used" and 4 "high effectiveness". With the same approach, we assessed the use of patenting as a source of competitiveness of product and process innovations on a 4-point Likert scale. Our dependent variable Patenting/(Patenting + Secrecy) is therefore constructed by dividing patenting by the sum of patenting and secrecy.

\section{Independent variables and moderators}

The literature has not established a single criterion to conceptualise and operationalise family firms. Many studies measure either the ownership of the firm held by family members and/or the number of family members in management positions (Hernández-Linares et al., 2018). However, other researchers have highlighted other features to define a family firm, such as the governance structure or the continuity of family ownership (Block, 2012; Covin et al., 2016). Given the challenges associated with capturing the essence of family firms, some authors have argued for a self-definition conceptualisation of family firms, where the principals in a business identify whether the firm is a family firm or not (Chua et al., 1999). In this paper, we operationalised family firms (Family firm) as those firms that the respondent self-identified as family firms when asked the question: "Do you consider the firm a family owned \&/or managed company? Yes or No". Hence, the questionnaire asked participating managers/owners whether their firms were family owned and/or managed or not. Thus, family firms were given a value of 1 , and non-family firms were given a value of 0 .

Proactive orientation was assessed using the three items (alpha $=0.72)$ developed by Covin and Slevin (1989) as a sub-scale of the entrepreneurial orientation construct (see Table 1 for the entrepreneurship scale). Specifically, the questionnaire asked firms to rate their degree of agreement along a 7-point Likert scale based on a continuum between two extreme characterisations of their firms' behaviour where 4 indicates a neutral position. The three items that measured proactive orientation are items 4, 5, and 6 on the entrepreneurship scale in Table 1. 


\section{Table 1 about here}

\section{$\underline{\text { Control Variables }}$}

Our analysis controlled for multiple factors that can affect the extent to which firms use patenting relative to secrecy. To control for the effects of the country we included three binary variables (France, Denmark, United States) to capture the differences in these countries compared to Italy, which is used as the baseline.

We controlled for a number of firm-level attributes. First, since proactive orientation is one of the three components of the broader construct of entrepreneurial orientation (Covin and Slevin, 1989), we also included the two other sub-scales of risk taking and innovativeness. Including the innovativeness sub-scale also allowed us to control for the firms' investment in new product and process innovations. Consistent with Covin and Slevin (1989), each of these variables was based on three 7-point Likert scale items based on a continuum between two extreme characterisations of their firms behaviour where 4 indicates a neutral position and 1 and 7 represent the two extreme characterisations. Risk taking was measured as a response to items 7, 8 and 9 and innovativeness was measured using items 1, 2 and 3 in Table 1. For our sample, the coefficient alphas for the three items included in our measures for Risk taking and Innovativeness, respectively, were 0.90 and 0.86 .

To control for the influence of managers' perceptions of firm brands, a control variable (Brand) was included based on a scale of five 7-point Likert-type items $(1=$ strongly disagree and $7=$ strongly agree; coefficient alpha $=0.85)$, which described the influence of different features of the company's brand on its strategic decision-making process. Specifically, the five statements included the following: 1) Our company's history influences how we make everyday business decisions, 2) We preserve the heritage of our brand when we make strategic decisions, 3) Preserving the timelessness of our brand is what we strive for when making key management decisions, 4) The values of our brand have not changed over time, and 5) We would rather be loyal to our company history than to change our branding in order to adapt to the market.

The use of other methods for fostering firm competitiveness of products and processes was controlled for by adding four single-item variables (Designs, Copyrights, Organic, Lead Time) respectively based on responses to the question: "How effective were (a) design registrations, (b) copyrights, (c) organic certifications, and (d) lead time 
advantages for maintaining or increasing firm competitiveness of products and processes over the last three years?" ( $1=$ not used and $4=$ high degree of effectiveness $)$.

Finally, we added a control for firm age, measured by the number of years since the firm was instituted (Firm age), and firm size, measured by the number of employees (Firm size). None of the firms in our sample had over 300 employees. Because some firms in the sample were only wineries or only vineyards, we also included two binary variables: Only winery equals 1 if the firm is only a winery and equals 0 otherwise; Only vineyard is coded as 1 if the firm is only a vineyard and 0 otherwise. In addition, because firms may exhibit different sensitivities to the use of trade secrets, depending on the nature of their business and, specifically in our sample, on the role of wine within the firm's business scope, we included a dummy variable (Primary business), which takes value 1 if wine is the firm's primary business and zero otherwise.

\section{Results}

Figure 1 displays the percentage of firms that use secrecy and patenting by country. In all cases the percentage of firms that use secrecy is higher than the percentage of firms that use patenting. Figure 1 shows that Denmark has the highest percentage of firms using secrecy, followed by United States, and, lastly, by France and Italy. This order is consistent with La Porta et al.'s (1998) findings regarding the effect of legal systems on preferences for patenting relative to secrecy across countries. Our analysis reveals that in countries with stronger legal enforcement systems, there is a greater reliance on secrecy than in countries with a weaker enforcement system. This is explained by the fact that in a strong IP system firms are more likely to be able to defend secrecy in a court case than in countries with a weak IP system. Alternatively, in a country with a weak IP system as the local legal framework, there is more room for interpretation in a secrecy case relative to a patent infringement case.

\section{Figure 1 about here}

Table 2 reports the descriptive statistics of the variables used in the analyses. The data reveals several interesting points. The mean value of Patenting/(Patenting + Secrecy) is 0.466 , with a standard deviation of 0.115 . Detailed data (not presented here but available from the authors upon request), show that $66 \%$ of the sample firms use the two equally, $9 \%$ use patenting more, whereas $25 \%$ of the firms use secrecy more than patents. 
However, this preference for secrecy significantly varies across countries. Figure 2 shows that in Italy, only 4\% of the firms opt for secrecy over patents, while in France $36 \%$ of the firms has a preference for secrecy, followed by Denmark (48\%), and the United States, where more than half of the firms sampled (56\%) prefer secrecy over patenting. The variable Proactive orientation is also shown to vary widely (from 3 to 21 ). In line with the prior evidence that wineries and vineyards are primarily family businesses, our data show that $87 \%$ of the sample are family firms.

\section{Figure 2 and Table 2 about here}

Correlation coefficients of the variables used in the estimations are reported in Table 3. None of the variables are sufficiently correlated to suggest multicollinearity problems in the data. However, to ensure that multicollinearity did not bias our results, we computed the average Variance Inflation Factors (VIFs) of all the variables included in our model and all of them are below the threshold of 10 commonly recommended, confirming that multicollinearity does not appear to be an issue. Note that as proposed, the Family firm variable is positively correlated with our dependent variable, and proactive orientation is negatively correlated to the preference of patenting relative to secrecy.

\section{Tables 3 and 4 about here}

Table 4 displays the regression results. We employ Ordinary Least Square (OLS) regressions to test our hypotheses. The independent variables were introduced one by one to test their significance. Specifically, Model 1 reports the results when only the control variables are included. In Model 2 we add the direct effect of the Family firm variable, and in Model 3 we add the direct effect of the Proactive orientation variable. Finally, Model 4 incorporates the interaction term of Proactive orientation*Family firm capturing the moderating effect of proactive orientation on the relationship between family versus non-family firms and the use of patenting over secrecy.

Hypothesis 1 suggests that family SMEs (as compared to non-family SMEs) have a preference for patenting relative to secrecy as a means to protect and capture value from IP. In Model 2 of Table 4 the coefficient for the Family firm variable is positive and significant $(\beta=0.046, \mathrm{p}<0.05)$ using a two tailed test, providing support for Hypothesis 1 . Hypothesis 2 focuses on the moderating effect of proactive orientation on the preference for patenting relative to secrecy in family SMEs relative to non-family SMEs. Using a 
two tailed test the coefficient for Proactivenss*Family firm is negative and marginally significant $(\beta=-0.007, \mathrm{p}<0.10)$ in Model 4, providing partial supports for Hypothesis 2. This finding suggests that, as family firms' proactive orientation increases, the preference of family firms for patenting relative to secrecy is mitigated. Figure 3 illustrates the moderating effect of SMEs' proactive orientation.

\section{Figure 3 about here}

A number of our control variables are also significantly related to our dependent variable (Table 4). We find that, relative to Italy and France, Denmark and the United States have a lower preference for patenting relative to secrecy in line with the preliminary findings based on our descriptive statistics. Our data, therefore, support our contention that family firms prefer patenting relative to secrecy, although this preference is also influenced by country characteristics. The coefficient for Copyright is positive and significant in all models, thus suggesting that firms that consider copyrights to be effective mechanisms to protect IP have a higher preference for patenting relative to secrecy. On the contrary, we find that the Lead time variable is negative and significant in all the models, suggesting that firms that consider lead time a more effective mechanism to protect IP have a lower preference for patenting over secrecy. Firm size was revealed to be negative and significant, meaning that a lower predilection for patenting relative to secrecy is also contingent upon the number of employees. Finally, firms that are only vineyards have a higher preference for patenting over secrecy.

\section{Robustness check}

To ensure the robustness of the above findings, we conducted several additional analyses. First, to check that our model is robust to other model specifications, we ran a Tobit analysis, since our dependent variable ranges from 0.2 to 0.8 . The robustness check supports our hypotheses, with coefficients keeping the same sign and significance levels of our reported findings (see Table 5 Models 1 and 2). Second, since France and Italy have similar legal systems (as pertains to weaker enforcement systems), we ran the regression analyses using a sub-sample consisting only of firms from these two countries. The pattern of proposed results for Hypothesis 1 and 2 were in the same direction and were statistically significant ( $\mathrm{p}<0.01$ and $\mathrm{p}<0.05$ in Table 5 Models 3 and 4 , respectively), providing additional support for our hypotheses. Third, we run a robustness test by 
including another control variable related to the number of new products firms had developed over the past three years compared to their primary competitors as an additional control for their investment in innovation. To construct this variable, we asked participants the following question: "Compared to your primary competitors, how would you compare this company's performance over the last three years, on a scale from $1=$ worse to $4=$ much better, in terms of the number of new products developed?" We then included this variable in the regression with all of the variables incorporated in Model 4 of Table 4, the results remained significant for our predictor variables at the same level, but this variable, new products was not significant (see Table 5 Models 5 and 6). This suggests that SMEs development of new products relative to their competitors in the wine industry does not affect the choice between patenting and secrecy as means of value protection and capture.

\section{Table 5 about here}

\section{Discussion}

We combine the SME literature on the behavioural agency approach and entrepreneurial orientation with innovation research on IP rights to consider the family versus non-family SMEs preferences for mechanisms to protect and extract value from their IP, specifically secrecy and patenting. First, our results show that family SMEs in the wine industry (an industry known to exhibit a prevalence of SMEs) are more likely to prefer to protect their IP with formal methods, such as patents, rather than secrecy. These results support and extend existing research suggesting that family firms are more risk averse than non-family firms (Kraiczy et al., 2015; Zahra, 2005). We posit that family SMEs seek to protect the firm's knowledge that underpins the SMEs successful performance and its socio-emotional wealth using patenting when possible, because doing so allows them to avoid risks associated with IP spillovers more common with the use of secrecy (Morris, 1998; Naldi et al., 2007).

Second, we consider how SMEs' proactive orientation can weaken family firms' preference for patenting relative to secrecy as a means of value protection and capture. Previous literature has analysed the effect of family involvement, an informal institution, on the relationship between the strength of formal IP rights institutions in a country and the firm's R\&D resource allocation decisions (Brinkerink and Rondi, 2020). However, 
R\&D decisions are related to family firms' inputs into the innovation process and not the mechanism they select to protect and capture the IP once it has been developed. Our results show that the decision of how to protect IP is much more complex than existing research would suggest. We extend this research by considering the preferences of family SMEs relative to non-family SMEs for choosing patents over secrecy to protect IP and how proactive orientation moderates this relationship. This research deepens our understanding of how SMEs make decisions about IP protection and provides insights into how innovation is protected and captured in family and non-family SMEs. The findings associated with the interaction term (Proactivenss *Family firm) suggest that, although family SMEs are more risk-averse and may seek to avoid risks associated with secrecy, the more proactive the SME, the more likely family firms are to adopt secrecy rather than patents to protect IP. Thus as proactive orientation increases the preference for family SMEs to use patents is weakened, i.e., they are more likely to choose secrecy over patents.

\section{Limitations and Future Research}

This article is not without limitations, primarily regarding the context and the methodology. Our context was the global wine industry, yet our sample only includes data from four countries, although many other countries have reputations for making wine (i.e., Spain, Germany, Argentina, etc.). We limited the number of countries in the sample due to the complexity of data collection, language issues, and increased coordination costs. Relatedly, the data collection from some of these four countries resulted in small sample sizes. However, the data come from two of the oldest wine-producing countries (France and Italy) and also from a country in which the wine industry is nascent (Denmark), strengthening the content validity of our results. Our measures also suggest that the multi-country data collected was internally reliable, and allowed us to control for differences in the country sub-samples. However, the data used in the study are from a single industry, the wine industry, which is agricultural in nature. SMEs engaging in the production of similar or associated industries in the agricultural sector (Fitz-Koch et al., 2018) may be similarly influenced by family participation in their strategic choices to patent instead of choosing to use secrecy (Basco, 2014). However, we should be cautious in generalising our conclusions to other industries, particularly those not based on 
agriculture. Yet, we posit that the wine industry is comparable to many industries dominated by SMEs, and thus serves as an appropriate context for the objectives of this article. We encourage future research to replicate and extend our contributions using larger samples, sampling from more countries, and different industry contexts.

Family firms are heterogeneous, and we did not distinguish between different types of family firms (Howorth et al., 2010). For this article, we applied a broad definition of family firm and allowed our respondents to self-identify whether or not the firm was a family owned and/or managed company, since the wine industry is dominated by familyowned and managed SMEs (Cordano et al., 2010; Thach, 2015; Williams and Spielmann, 2019). We encourage future research to further explore the distinction between ownership and management. Additionally, we focused explicitly on SMEs' proactive orientation as a driving factor of family firms' preference for patenting relative to secrecy as a method for protecting their IP. We do so partly due to the strong link in the SME literature to the tendency for risk aversion in family firms and partly because less SME research has considered the effects of proactive orientation than risk taking and innovation. Nevertheless, we control for the other components of the broader construct of entrepreneurial orientation. We encourage researchers to further explore the relationship between the sub-scales of entrepreneurial orientation and SMEs' preferences for methods to protect IP.

Another caveat to our study relates to the preference for patenting since our theorising focuses on the extent in which patents (and trade secrets) are effective for maintaining or increasing firm competitiveness, but it does not directly address the question of whether SMEs are able to register a new patent. However, the ability to patent depends on three features: novelty, inventive step and industrial application. Certainly, wine recipes do possess these characteristics and are patentable. Furthermore, we know there has been a steep increase in recent years in the number of patents for wine (e.g. searching in Google for patents for "wine" and "recipe" shows 20,260 results), so wine recipes would be patentable, but firms might choose other IP protection mechanisms, particularly if they are small or cash constrained. Relatedly, although we could not control for R\&D expenditures, we did include innovativeness in our model, to control for firms that might not patent because they do not invest in innovation. We also conducted a robustness test where we incorporated a second control for innovation (the number of 
new products the firm developed in the past three years compared to their primary competitors) and our findings remained consistent and significant.

Finally, this article focused on how family SMEs relative to non-family SMEs protect and capture value from IP using patenting rather than secrecy and how a proactive orientation weakens this relationship, contributing to the literature on innovation in family firms. We encourage future research to consider how other characteristics of family SMEs directly affect their preferences for patents versus secrecy, and how they moderate the relationship between family SMEs' innovation inputs, such as R\&D investments, and their preference for patents relative to secrecy.

\section{Conclusion}

\section{Contributions to Theory}

The objective of this article was to investigate how family SMEs differ from nonfamily SMEs in regards to their preferences for adopting patenting and secrecy. Our study finds that family SMEs are more likely to choose patenting relative to secrecy than nonfamily SMEs. We also found that an increase in SMEs' proactive orientation weakens this relationship. In other words, family SMEs that are led by highly proactive management are less likely to use patenting relative to secrecy.

Our article contributes to the IP rights and SME literatures by explaining and empirically assessing firm characteristics that influence how effective family and nonfamily SMEs consider patenting and secrecy for maintaining or increasing the competitiveness of their product and process innovations. Value capturing studies in the IP rights literature have focused primarily on country, industry, and innovation type, and have failed to recognise the impact of firm level characteristics upon this important strategic decision. In the same way, the SME literature has said little about the preferences of family SMEs relative to non-family SMEs for patenting relative to secrecy. This article addresses this gap in these literatures by considering the importance of two firm-level characteristics: family SMEs relative to non-family SMEs and their proactive orientation. In particular, we found that family SMEs (as compared to non-family SMEs) are associated with more use of patenting than secrecy as a means to maintain and increase their competitiveness and capture value from IP. Moreover, we found that increases in the proactive orientation of SMEs weakens the relationship between family SMEs 
compared to non-family SMEs and their preferences for patenting relative to secrecy. Our findings therefore suggest that firm-level characteristics significantly contribute to our understanding of when SMEs use patents rather than secrecy, expanding the organisational factors identified by Bos et al. (2015) in the IP literature.

We also extend the entrepreneurial orientation literature by considering how SMEs' proactive orientation weakens the relationship between family and non-family SMEs and their assessment of how effective patenting is relative to secrecy as a method for maintaining or increasing the competitiveness of their product and process innovations. There are two contradictory streams of thought in literature regarding the innovative and entrepreneurial behaviour of family firms. We acknowledge the heterogeneity in family firms characteristics, and consider specifically how the level of proactive orientation differs across firms, while other scholars have found a number of factors, such as family dynamics (De Massis et al., 2014) and environmental factors (Casillas et al., 2011), that influence it. On this basis, we advocate that the methods firms use to capture value are moderated by the proactive orientation of the family SME.

\section{Contributions to Practice}

In addition to deepening our theoretical understanding of how family SMEs make decisions regarding IP protection, our article also contributes to practice. Our results provide managers of family SMEs with greater insights into how decisions are made regarding strategies to protect IP and the impact that risk-aversion and proactive orientation have upon the use of secrecy. More specifically, it reveals that although family firms may be risk-averse, leading to more use of patents, when management is more proactive, family firms are less likely to prefer patents. We propose that the proactive orientation of family SMEs makes them focus more on possible opportunities to enhance and leverage the long-term viability and socio-emotional wealth of the business, by using secrecy as a means of value capture rather than taking the time and investing in the costs associated with protecting the firms' IP using patenting. Thus family firms are encouraged to audit themselves in terms of proactive orientation before considering investing in patenting.

In conclusion, this article extends our understanding of the firm-level factors that influence when SMEs are more likely to use formal IP instead of secrecy, as well as when 
they are more likely to use secrecy instead of patenting. Our findings show that firm type, in terms of family versus non-family, and proactive orientation influence the likelihood that SMEs will choose patents over secrecy as a method to protect value of their IP.

\section{References}

Alcácer J, Beukel K and Cassiman B (2017) Capturing Value from Intellectual Property (IP) in a Global Environment. In: Geography, Location, and Strategy. Advances in Strategic Management 36. Emerald Publishing Limited, pp. 163-228. DOI: 10.1108/S0742-332220170000036006.

Ardito L, Petruzzelli AM, Pascucci F, et al. (2019) Inter-firm R\&D collaborations and green innovation value: The role of family firms' involvement and the moderating effects of proximity dimensions. Business Strategy and the Environment 28(1): 185-197. DOI: 10.1002/bse.2248.

Arundel A (2001) The relative effectiveness of patents and secrecy for appropriation. Research Policy 30(4): 611-624. DOI: 10.1016/S0048-7333(00)00100-1.

Bannò M (2016) Propensity to patent by family firms. Journal of Family Business Strategy 4(7): 238-248. DOI: 10.1016/j.jfbs.2016.07.002.

Basco R (2014) Exploring the influence of the family upon firm performance: Does strategic behaviour matter? International Small Business Journal 32(8): 967995. DOI: $10.1177 / 0266242613484946$.

Block J, Miller D, Jaskiewicz P, et al. (2013) Economic and Technological Importance of Innovations in Large Family and Founder Firms: An Analysis of Patent Data. Family Business Review 26(2): 180-199. DOI: 10.1177/0894486513477454.

Block JH (2012) R\&D investments in family and founder firms: An agency perspective. Journal of Business Venturing 27(2): 248-265. DOI: 10.1016/j.jbusvent.2010.09.003.

Bos B, Broekhuizen TLJ and de Faria P (2015) A dynamic view on secrecy management. Journal of Business Research 68(12): 2619-2627. DOI: 10.1016/j.jbusres.2015.04.009.

Brinkerink J and Rondi E (2020) When Can Families Fill Voids? Firms' Reliance on Formal and Informal Institutions in R\&D Decisions. Entrepreneurship Theory and Practice: 1042258719899423. DOI: $10.1177 / 1042258719899423$.

Brislin RW (1970) Back-Translation for Cross-Cultural Research. Journal of CrossCultural Psychology 1(3): 185-216. DOI: 10.1177/135910457000100301. 
Carney M (2005) Corporate Governance and Competitive Advantage in FamilyControlled Firms. Entrepreneurship Theory and Practice 29(3): 249-265. DOI: 10.1111/j.1540-6520.2005.00081.x.

Casillas JC, Moreno AM and Barbero JL (2011) Entrepreneurial orientation of family firms: Family and environmental dimensions. Journal of Family Business Strategy 2(2): 90-100. DOI: 10.1016/j.jfbs.2011.03.002.

Chen H-L and Hsu W-T (2009) Family Ownership, Board Independence, and R\&D Investment. Family Business Review 22(4): 347-362. DOI: 10.1177/0894486509341062.

Chidlow A, Plakoyiannaki E and Welch C (2014) Translation in cross-language international business research: Beyond equivalence. Journal of International Business Studies 45(5): 562-582. DOI: 10.1057/jibs.2013.67.

Chirico F and Nordqvist M (2010) Dynamic capabilities and trans-generational value creation in family firms: The role of organizational culture. International Small Business Journal 28(5): 487-504. DOI: 10.1177/0266242610370402.

Chirico F, Criaco G, Baù M, et al. (2018) To patent or not to patent: That is the question. Intellectual property protection in family firms. Entrepreneurship Theory and Practice: 1042258718806251. DOI: $10.1177 / 1042258718806251$.

Chrisman JJ and Patel PC (2012) Variations in R\&D Investments of Family and Nonfamily Firms: Behavioral Agency and Myopic Loss Aversion Perspectives. Academy of Management Journal 55(4): 976-997. DOI: 10.5465/amj.2011.0211.

Chua JH, Chrisman JJ and Sharma P (1999) Defining the Family Business by Behavior. Entrepreneurship: Theory and Practice 23(4): 19-19.

Cohen WM, Goto A, Nagata A, et al. (2002) R\&D spillovers, patents and the incentives to innovate in Japan and the United States. Research Policy 31(8-9): 13491367. DOI: 10.1016/S0048-7333(02)00068-9.

Cordano M, Marshall RS and Silverman M (2010) How do Small and Medium Enterprises Go "Green"? A Study of Environmental Management Programs in the U.S. Wine Industry. Journal of Business Ethics 92(3): 463-478. DOI: 10.1007/s10551-009-0168-z.

Covin JG and Slevin DP (1989) Strategic management of small firms in hostile and benign environments. Strategic Management Journal 10(1): 75-87. DOI: 10.1002/smj.4250100107.

Covin JG, Eggers F, Kraus S, et al. (2016) Marketing-related resources and radical innovativeness in family and non-family firms: A configurational approach. Journal of Business Research 12(69): 5620-5627. DOI: 10.1016/j.jbusres.2016.03.069. 
Craig JB, Pohjola M, Kraus S, et al. (2014) Exploring Relationships among Proactiveness, Risk-Taking and Innovation Output in Family and Non-Family Firms. Creativity and Innovation Management 23(2): 199-210. DOI: 10.1111/caim.12052.

Crittenden WF, Crittenden VL and Pierpont A (2015) Trade secrets: Managerial guidance for competitive advantage. Business Horizons 58(6). SPECIAL ISSUE: THE MAGIC OF SECRETS: 607-613. DOI: 10.1016/j.bushor.2015.06.004.

Crowley P (2004) Innovation in the new Member States and Candidate CountriesOutput, barriers and protection. 13. Statistics in focus-science and technology, European Communities.

De Massis A, Chirico F, Kotlar J, et al. (2014) The Temporal Evolution of Proactiveness in Family Firms: The Horizontal S-Curve Hypothesis. Family Business Review 27(1): 35-50. DOI: 10.1177/0894486513506114.

Denicolò V and Franzoni LA (2004) Patents, Secrets, and the First-Inventor Defense. Journal of Economics \& Management Strategy 13(3): 517-538. DOI: 10.1111/j.1430-9134.2004.00021.x.

Envick BR, Langford M and Ward SG (2008) Using Family Firm Boundary Management Theory to Explain the Impact of Privacy Issues on Family Firm Research. Academy of Entrepreneurship Journal; Arden 14(1/2): 37-49.

Fitz-Koch S, Nordqvist M, Carter S, et al. (2018) Entrepreneurship in the Agricultural Sector: A Literature Review and Future Research Opportunities. Entrepreneurship Theory and Practice 42(1): 129-166. DOI: $10.1177 / 1042258717732958$.

Fletcher D (2002) Understanding the Small Family Business. Routledge.

Gan K, Saleh Z and Abessi M (2013) Ownership Structure and Voluntary Disclosure of Intellectual Capital: Evidence from Malaysia. In: Ndubisi NO (ed.) Enterprise Development in SMEs and Entrepreneurial Firms: Dynamic Processes. USA: IGI GLOBAL, pp. 390-404. DOI: 10.4018/978-1-4666-2952-3.ch022.

Garcés-galdeano L, Larraza-kintana M, García-olaverri C, et al. (2016) Entrepreneurial orientation in family firms: the moderating role of technological intensity and performance. International Entrepreneurship and Management Journal; New York 12(1): 27-45. DOI: http://0-dx.doi.org.cisne.sim.ucm.es/10.1007/s11365014-0335-2.

Gick W (2008) Little Firms and Big Patents: A Model of Small-Firm Patent Signaling. Journal of Economics \& Management Strategy 17(4): 913-935. DOI: 10.1111/j.1530-9134.2008.00200.x.

Gómez-Mejía LR, Haynes KT, Núñez-Nickel M, et al. (2007) Socioemotional Wealth and Business Risks in Family-controlled Firms: Evidence from Spanish Olive 
Oil Mills. Administrative Science Quarterly 52(1): 106-137. DOI:

10.2189/asqu.52.1.106.

Hall B, Helmers C, Rogers M, et al. (2014) The Choice between Formal and Informal Intellectual Property: A Review. Journal of Economic Literature 52(2): 375423. DOI: $10.1257 /$ jel.52.2.375.

Hall D, Pitt L and Wallstrom A (2015) The secrets of secret societies: The case of wine. Business Horizons 58(6). SPECIAL ISSUE: THE MAGIC OF SECRETS: 651658. DOI: 10.1016/j.bushor.2015.07.002.

Hernández-Linares R and López-Fernández MC (2018) Entrepreneurial Orientation and the Family Firm: Mapping the Field and Tracing a Path for Future Research. Family Business Review 31(3): 318-351. DOI: 10.1177/0894486518781940.

Hernández-Linares R, Sarkar S and Cobo MJ (2018) Inspecting the Achilles heel: a quantitative analysis of 50 years of family business definitions. Scientometrics 115(2): 929-951. DOI: 10.1007/s11192-018-2702-1.

Holgersson M (2013) Patent management in entrepreneurial SMEs: a literature review and an empirical study of innovation appropriation, patent propensity, and motives. $R \& D$ Management 43(1): 21-36. DOI: 10.1111/j.14679310.2012.00700.x.

Howorth C, Rose M, Hamilton E, et al. (2010) Family firm diversity and development: An introduction. International Small Business Journal 28(5): 437-451. DOI: $10.1177 / 0266242610373685$.

Howorth C, Jackson J and Discua Cruz A (2014) Entrepreneurship in family businesses. In: Chell E and Karatas-Ozkan M (eds) Handbook of Research in Small Business and Entrepreneurship. Edward Elgar, pp. 333-357.

Intihar A and Pollack JM (2012) Exploring small family-owned firms' competitive ability: Differentiation through trust, value-orientation, and market specialization. Journal of Family Business Management 2(1): 76-86. DOI: 10.1108/20436231211216439.

Jackson RS (2017) Chapter 13 - Innovations in Winemaking. In: Kosseva MR, Joshi VK, and Panesar PS (eds) Science and Technology of Fruit Wine Production. San Diego: Academic Press, pp. 617-662. DOI: 10.1016/B978-0-12-8008508.00013-2.

James SD, Leiblein MJ and Lu S (2013) How Firms Capture Value From Their Innovations. Journal of Management 39(5): 1123-1155. DOI: 10.1177/0149206313488211.

Janjuha-Jivraj S and Spence LJ (2009) The Nature of Reciprocity in Family Firm Succession. International Small Business Journal 27(6): 702-719. DOI: 10.1177/0266242609344252. 
Jell F, Block JH, Henkel J, et al. (2015) Cross-functional patent management in family firms. Journal of Business Economics 85(2): 181-203. DOI: 10.1007/s11573014-0732-6.

Kets de Vries MFR (1993) The Dynamics of Family Controlled Firms: The Good and the Bad News. Organizational Dynamics 21(3): 59-71.

Kraiczy ND, Hack A and Kellermanns FW (2015) What Makes a Family Firm Innovative? CEO Risk-Taking Propensity and the Organizational Context of Family Firms. Journal of Product Innovation Management 32(3): 334-348. DOI: 10.1111/jpim.12203.

La Porta R, Lopez-de-Silanes F, Shleifer A, et al. (1998) Law and Finance. Journal of Political Economy 106(6): 1113-1155. DOI: 10.1086/250042.

Leiponen A and Byma J (2009) If you cannot block, you better run: Small firms, cooperative innovation, and appropriation strategies. Research Policy 38(9): 1478-1488. DOI: 10.1016/j.respol.2009.06.003.

Lieberman MB and Montgomery DB (1988) First-mover advantages. Strategic Management Journal 9(S1): 41-58. DOI: 10.1002/smj.4250090706.

Lippman SA and Rumelt RP (2003) A bargaining perspective on resource advantage. Strategic Management Journal 24(11): 1069-1086. DOI: 10.1002/smj.345.

Llach J and Nordqvist M (2010) Innovation in family and non-family businesses: a resource perspective. International Journal of Entrepreneurial Venturing 2(3): 381-399. DOI: 10.1504/IJEV.2010.037119.

Lomberg C, Urbig D, Stöckmann C, et al. (2017) Entrepreneurial Orientation: The Dimensions' Shared Effects in Explaining Firm Performance. Entrepreneurship Theory and Practice 41(6): 973-998. DOI: 10.1111/etap.12237.

Lubatkin MH, Ling Y and Schulze WS (2007) An Organizational Justice-Based View of Self-Control and Agency Costs in Family Firms. Journal of Management Studies 44(6): 955-971. DOI: 10.1111/j.1467-6486.2006.00673.x.

Matzler K, Veider V, Hautz J, et al. (2015) The Impact of Family Ownership, Management, and Governance on Innovation. Journal of Product Innovation Management 32(3): 319-333. DOI: 10.1111/jpim.12202.

Melin L, Nordqvist M and Sharma P (2014) The SAGE Handbook of Family Business. SAGE.

Miller D (1983) The Correlates of Entrepreneurship in Three Types of Firms. Management Science 29(7): 770-791. DOI: 10.1287/mnsc.29.7.770.

Morris MH (1998) Entrepreneurial Intensity: Sustainable Advantages for Individuals, Organizations, and Societies. Greenwood Publishing Group. 
Naldi L, Nordqvist M, Sjöberg K, et al. (2007) Entrepreneurial Orientation, Risk Taking, and Performance in Family Firms. Family Business Review 20(1): 3347. DOI: 10.1111/j.1741-6248.2007.00082.x.

Nordqvist M, Habbershon TG and Melin L (2008) Transgenerational entrepreneurship: exploring entrepreneurial orientation in family firms. In: Entrepreneurship, Sustainable Growth and Performance: Frontiers in European Entrepreneurship Research.

Podsakoff PM, MacKenzie SB, Lee J-Y, et al. (2003) Common method biases in behavioral research: a critical review of the literature and recommended remedies. The Journal of Applied Psychology 88(5): 879-903. DOI: 10.1037/0021-9010.88.5.879.

Schmid T, Achleitner A-K, Ampenberger M, et al. (2014) Family firms and R\&D behavior - New evidence from a large-scale survey. Research Policy 43(1): 233-244. DOI: 10.1016/j.respol.2013.08.006.

Sharma P and Manikutty S (2005) Strategic Divestments in Family Firms: Role of Family Structure and Community Culture. Entrepreneurship Theory and Practice 29(3): 293-311. DOI: 10.1111/j.1540-6520.2005.00084.x.

Sofka W, de Faria P and Shehu E (2018) Protecting knowledge: How legal requirements to reveal information affect the importance of secrecy. Research Policy 47(3): 558-572.

Spielman N, Cruz AD, Tyler BB, et al. (2019) Place as a nexus for corporate heritage identity: An international study of family-owned wineries. Journal of Business Research. DOI: 10.1016/j.jbusres.2019.05.024.

Thach L (2015) Best Practices in Global Wine Tourism: 15 Case Studies from Around the World (S Chartersed. ). Putnam Valley, NY: Miranda Press.

Tognazzo A, Destro F and Gubitta P (2013) Patenting in family firms. International Journal of Entrepreneurship and Innovation Management 17(1/2/3): 84-104.

Veugelers R and Schneider C (2018) Which IP strategies do young highly innovative firms choose? Small Business Economics 50(1): 113-129. DOI: 10.1007/s11187-017-9898-y.

Vrontis D and Paliwoda SJ (2008) Branding and the Cyprus wine industry. Journal of Brand Management 16(3): 145-159. DOI: 10.1057/bm.2008.1.

Ward JL (1997) Growing the Family Business: Special Challenges and Best Practices. Family Business Review 10(4): 323-337. DOI: 10.1111/j.17416248.1997.00323.x.

Williams C and Spielmann N (2019) Institutional pressures and international market orientation in SMEs: Insights from the French wine industry. International Business Review. DOI: 10.1016/j.ibusrev.2019.05.002. 
Woodfield P and Husted K (2017) Intergenerational knowledge sharing in family firms: Case-based evidence from the New Zealand wine industry. Journal of Family Business Strategy 8(1): 57-69. DOI: 10.1016/j.jfbs.2017.01.001.

Zahra SA (2005) Entrepreneurial Risk Taking in Family Firms. Family Business Review 18(1): 23-40. DOI: 10.1111/j.1741-6248.2005.00028.x.

Zahra SA, Hayton JC and Salvato C (2004) Entrepreneurship in Family vs. Non-Family Firms: A Resource-Based Analysis of the Effect of Organizational Culture. Entrepreneurship Theory and Practice 28(4): 363-381. DOI: 10.1111/j.15406520.2004.00051.x.

Zellweger T and Sieger P (2012) Entrepreneurial orientation in long-lived family firms. Small Business Economics 38(1): 67-84. DOI: 10.1007/s11187-010-9267-6. 


\section{Tables and Figures}

Table 1: Entrepreneurship scale by Covin and Slevin (1989) used in this study.

Please rate the extent to which you agree with the following items related to your business's strategic posture, with the number 4 indicating a neutral position.

I1. In general, the top managers of my business unit favor...
A strong emphasis on the
122345567
A strong emphasis on $\mathrm{R} \& \mathrm{D}$, marketing of tried and true technological leadership, and products or services innovations

I2. How many new lines of products or services has your business unit marketed during the past three years?

No new lines of products or

122345567

services

1234567

I3. Changes in product or service lines have been mostly of a minor nature

Very many new lines of products or services

Changes in product or service lines have usually been quite dramatic

P4. In dealing with its competitors, my business unit...

Typically responds to actions $\quad 1234567$ which competitors initiate

$\begin{array}{llllllll}1 & 2 & 3 & 4 & 5 & 6 & 7\end{array}$ Is very often the first business to P5.Is very seldom the first business to introduce new introduce new products/services, administrative techniques, operating technologies, etc.

P6. Typically seeks to avoid 1234567 competitive clashes, preferring a "live-and-let-live" posture R7. In general, top managers of my business unit have... A strong proclivity for low risk $\quad 1234567$ projects (with normal and clivity for high risk projects (with chances for very certain rates of return) high returns)

R8. In general, the top managers of my business unit have...

Owing to the nature of the $\quad 1234567$ environment, it is best to explore it gradually via cautious, incremental behaviour products/services, administrative techniques, operating technologies, etc.

Typically adopts a very competitive "undo-thecompetitors" posture

R9. When confronted with decision making situations involving uncertainty, my business unit...

Typically adopts a cautious

Typically adopts a bold, "wait and see" posture in order to minimise the probability of making costly decisions

Owing to the nature of the environment, bold, wideranging acts are necessary to achieve the firm's objectives aggressive posture in order to maximise the probability of exploiting potential opportunities 
Table 2: Descriptive statistics

\begin{tabular}{lrrrr}
\hline Variable & Mean & Std. Dev. & Min & \multicolumn{2}{c}{ Max } \\
\hline Patenting/(Patenting+Secrecy) & .466 & .115 & .2 & .8 \\
Family firm & .867 & .340 & 0 & 1 \\
Proactive orientation & 11.637 & 3.832 & 3 & 21 \\
Italy & .457 & .498 & 0 & 1 \\
France & .357 & .479 & 0 & 1 \\
Denmark & .103 & .304 & 0 & 1 \\
United States & .083 & .276 & 0 & 1 \\
Risk taking & 11.19 & 4.328 & 3 & 21 \\
Innovativeness & 11.593 & 5.059 & 3 & 21 \\
Brand & 25.147 & 6.439 & 5 & 35 \\
Designs & 1.57 & .913 & 1 & 4 \\
Copyrights & 1.34 & .720 & 1 & 4 \\
Organic & 1.92 & 1.199 & 1 & 4 \\
Leadtime & 2.03 & 1.026 & 1 & 4 \\
Firm Age & 50.883 & 67.849 & 0 & 760 \\
Firm Size & 10.397 & 26.885 & 0 & 300 \\
Only Winery & .073 & .261 & 0 & 1 \\
Only Vineyard & .047 & .211 & 0 & 1 \\
Primarybusiness & .917 & .277 & 0 & 1 \\
\hline & & & &
\end{tabular}


Table 3 Pairwise correlations

\begin{tabular}{|c|c|c|c|c|c|c|c|c|c|c|c|c|c|c|c|c|c|c|}
\hline & 1 & 2 & 3 & 4 & 5 & 6 & 7 & 8 & 9 & 10 & 11 & 12 & 13 & 14 & 15 & 16 & 17 & 18 \\
\hline 1 Patenting/(Patenting+Secrecy) & 1.000 & & & & & & & & & & & & & & & & & \\
\hline 2 Family firm & 0.199 & 1.000 & & & & & & & & & & & & & & & & \\
\hline 3 Proactive orientation & -0.105 & 0.032 & 1.000 & & & & & & & & & & & & & & & \\
\hline 4 Italy & 0.209 & -0.074 & 0.166 & 1.000 & & & & & & & & & & & & & & \\
\hline 5 France & -0.088 & -0.015 & -0.207 & -0.683 & 1.000 & & & & & & & & & & & & & \\
\hline 6 Denmark & -0.105 & 0.037 & 0.087 & -0.311 & -0.253 & 1.000 & & & & & & & & & & & & \\
\hline 7 United States & -0.109 & 0.118 & -0.034 & -0.276 & -0.225 & -0.102 & 1.000 & & & & & & & & & & & \\
\hline 8 Risk taking & -0.830 & 0.035 & 0.654 & -0.048 & -0.097 & 0.211 & 0.023 & 1.000 & & & & & & & & & & \\
\hline 9 Innovativeness & -0.011 & -0.016 & 0.514 & 0.249 & -0.235 & 0.062 & -0.109 & 0.582 & 1.000 & & & & & & & & & \\
\hline 10 Brand & 0.143 & 0.120 & -0.050 & 0.246 & -0.107 & -0.183 & -0.056 & -0.115 & -0.064 & 1.000 & & & & & & & & \\
\hline 11 Designs & 0.128 & -0.056 & 0.086 & 0.168 & -0.175 & 0.028 & -0.030 & 0.055 & 0.110 & 0.045 & 1.000 & & & & & & & \\
\hline 12 Copyrights & 0.159 & -0.033 & 0.122 & 0.050 & -0.139 & 0.129 & 0.008 & 0.133 & 0.072 & 0.091 & 0.599 & 1.000 & & & & & & \\
\hline 13 Organic & 0.050 & -0.067 & 0.206 & 0.017 & 0.073 & -0.032 & -0.121 & 0.167 & 0.116 & -0.052 & 0.081 & 0.101 & 1.000 & & & & & \\
\hline 14 Leadtime & -0.036 & -0.084 & 0.336 & 0.313 & -0.205 & -0.106 & -0.091 & 0.128 & 0.187 & 0.031 & 0.396 & 0.357 & 0.103 & 1.000 & & & & \\
\hline 15 Firm Age & -0.026 & -0.022 & 0.008 & 0.063 & 0.151 & -0.198 & -0.157 & -0.008 & 0.020 & -0.007 & 0.003 & -0.013 & 0.039 & 0.031 & 1.000 & & & \\
\hline 16 Firm Size & -0.099 & -0.158 & 0.194 & 0.098 & -0.060 & -0.118 & 0.057 & 0.057 & -0.017 & 0.077 & 0.086 & 0.128 & -0.000 & 0.178 & 0.130 & 1.000 & & \\
\hline 17 Only Winery & -0.020 & -0.266 & 0.020 & 0.127 & -0.156 & -0.095 & 0.147 & 0.053 & 0.109 & -0.008 & 0.006 & 0.028 & -0.067 & 0.054 & 0.004 & 0.054 & 1.000 & \\
\hline 18 Only Vineyard & 0.050 & -0.006 & -0.053 & -0.108 & -0.033 & 0.029 & 0.219 & -0.068 & -0.126 & -0.034 & -0.086 & -0.083 & -0.038 & -0.053 & -0.103 & 0.109 & -0.062 & 1.000 \\
\hline 19 Primary business & 0.006 & 0.024 & -0.019 & 0.083 & 0.124 & -0.373 & 0.047 & -0.031 & -0.029 & 0.104 & 0.069 & 0.059 & -0.000 & 0.103 & 0.053 & 0.076 & 0.039 & -0.048 \\
\hline
\end{tabular}


Table 4: OLS regression results: dependent variable is Patenting/(Patenting +Secrecy)

\begin{tabular}{|c|c|c|c|c|}
\hline & Model 1 & Model 2 & Model 3 & Model 4 \\
\hline \multirow[t]{2}{*}{ Family firm } & & $0.046 * *$ & $0.048 * *$ & $0.131 * *$ \\
\hline & & {$[0.020]$} & {$[0.021]$} & {$[0.052]$} \\
\hline \multirow[t]{2}{*}{ Proactive orientation } & & & -0.003 & 0.003 \\
\hline & & & {$[0.002]$} & {$[0.004]$} \\
\hline \multirow{2}{*}{$\begin{array}{l}\text { Family firm* Proactive } \\
\text { orientation }\end{array}$} & & & & \\
\hline & & & & $\begin{array}{c}-0.007 * \\
{[0.004]}\end{array}$ \\
\hline \multirow[t]{2}{*}{ France } & $-0.047 * * *$ & $-0.046 * * *$ & $-0.049 * * *$ & $-0.050 * * *$ \\
\hline & [0.016] & {$[0.016]$} & [0.016] & [0.016] \\
\hline \multirow[t]{2}{*}{ Denmark } & $-0.095 * * *$ & $-0.097 * * *$ & $-0.098 * * *$ & $-0.102 * * *$ \\
\hline & [0.030] & {$[0.030]$} & [0.029] & {$[0.030]$} \\
\hline \multirow[t]{2}{*}{ United States } & $-0.087 * * *$ & $-0.098 * * *$ & $-0.099 * * *$ & $-0.101 * * *$ \\
\hline & [0.027] & {$[0.027]$} & {$[0.027]$} & {$[0.027]$} \\
\hline \multirow{2}{*}{ Risk taking } & -0.001 & -0.001 & 0.001 & 0.001 \\
\hline & [0.002] & [0.002] & [0.002] & {$[0.002]$} \\
\hline \multirow{2}{*}{ Innovativeness } & -0.001 & -0.001 & -0.000 & -0.000 \\
\hline & [0.002] & [0.002] & {$[0.002]$} & {$[0.002]$} \\
\hline \multirow[t]{2}{*}{ Brand } & 0.001 & 0.001 & 0.001 & 0.001 \\
\hline & [0.001] & [0.001] & [0.001] & [0.001] \\
\hline \multirow[t]{2}{*}{ Designs } & 0.007 & 0.008 & 0.007 & 0.007 \\
\hline & [0.010] & {$[0.010]$} & {$[0.010]$} & {$[0.010]$} \\
\hline \multirow[t]{2}{*}{ Copyrights } & $0.036 * *$ & $0.036 * *$ & $0.035 * *$ & $0.035 * * *$ \\
\hline & {$[0.014]$} & {$[0.014]$} & {$[0.014]$} & [0.013] \\
\hline \multirow[t]{2}{*}{ Organic } & 0.004 & 0.004 & 0.005 & 0.005 \\
\hline & [0.005] & {$[0.005]$} & {$[0.005]$} & {$[0.005]$} \\
\hline \multirow[t]{2}{*}{ Leadtime } & $-0.021 * * *$ & $-0.021 * * *$ & $-0.018 * *$ & $-0.017 * *$ \\
\hline & [0.007] & [0.007] & {$[0.008]$} & [0.008] \\
\hline \multirow{2}{*}{ Firm Age } & -0.000 & -0.000 & -0.000 & -0.000 \\
\hline & {$[0.000]$} & {$[0.000]$} & {$[0.000]$} & {$[0.000]$} \\
\hline \multirow[t]{2}{*}{ Firm Size } & $-0.001 * * *$ & $-0.000 * *$ & $-0.000 * *$ & $-0.000 * *$ \\
\hline & [0.000] & {$[0.000]$} & [0.000] & {$[0.000]$} \\
\hline \multirow{2}{*}{ Only Winery } & -0.007 & 0.010 & 0.008 & 0.005 \\
\hline & [0.031] & [0.032] & [0.032] & {$[0.033]$} \\
\hline \multirow[t]{2}{*}{ Only Vineyard } & $0.064 *$ & $0.067 * *$ & $0.066 * *$ & $0.066 * *$ \\
\hline & [0.034] & {$[0.032]$} & {$[0.032]$} & {$[0.033]$} \\
\hline \multirow[t]{2}{*}{ Primary business } & -0.017 & -0.019 & -0.020 & -0.021 \\
\hline & [0.020] & [0.021] & {$[0.022]$} & [0.022] \\
\hline \multirow{2}{*}{ Constant } & $0.483 * * *$ & $0.453 * * *$ & $0.466 * * *$ & $0.406 * * *$ \\
\hline & {$[0.042]$} & [0.044] & {$[0.043]$} & {$[0.056]$} \\
\hline R-squared & 0.149 & 0.165 & 0.171 & 0.179 \\
\hline Adj.R-squared & .104 & .118 & .121 & .127 \\
\hline No of Obs & 300 & 300 & 300 & 300 \\
\hline F test & $3.415 * * *$ & $3.659 * * *$ & $3.678 * * *$ & $3.587 * * *$ \\
\hline
\end{tabular}


Table 5: Robustness checks

Tobit Analysis

France and Italy

New Products

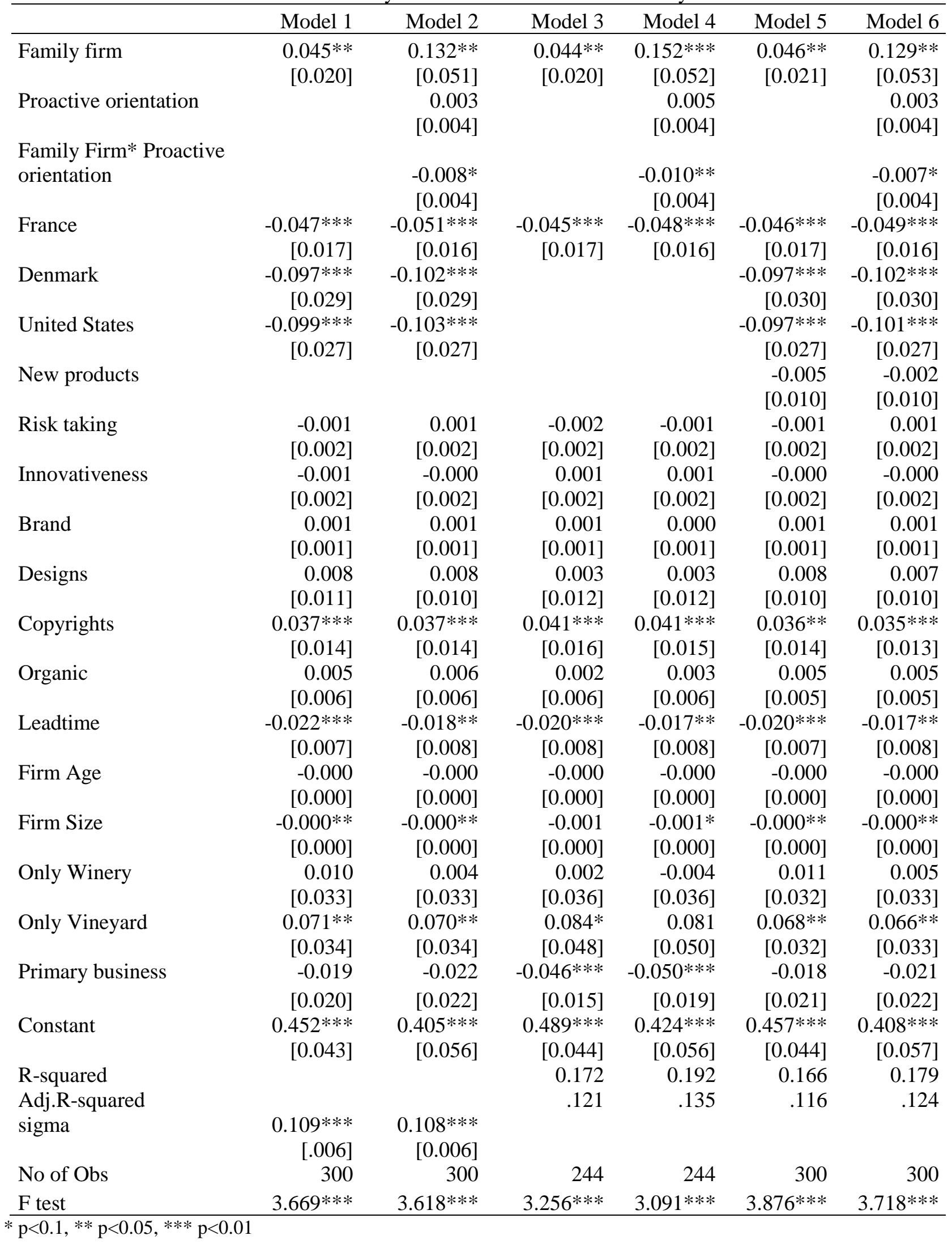


Figure 1: The percentage of firms that use secrecy and patenting

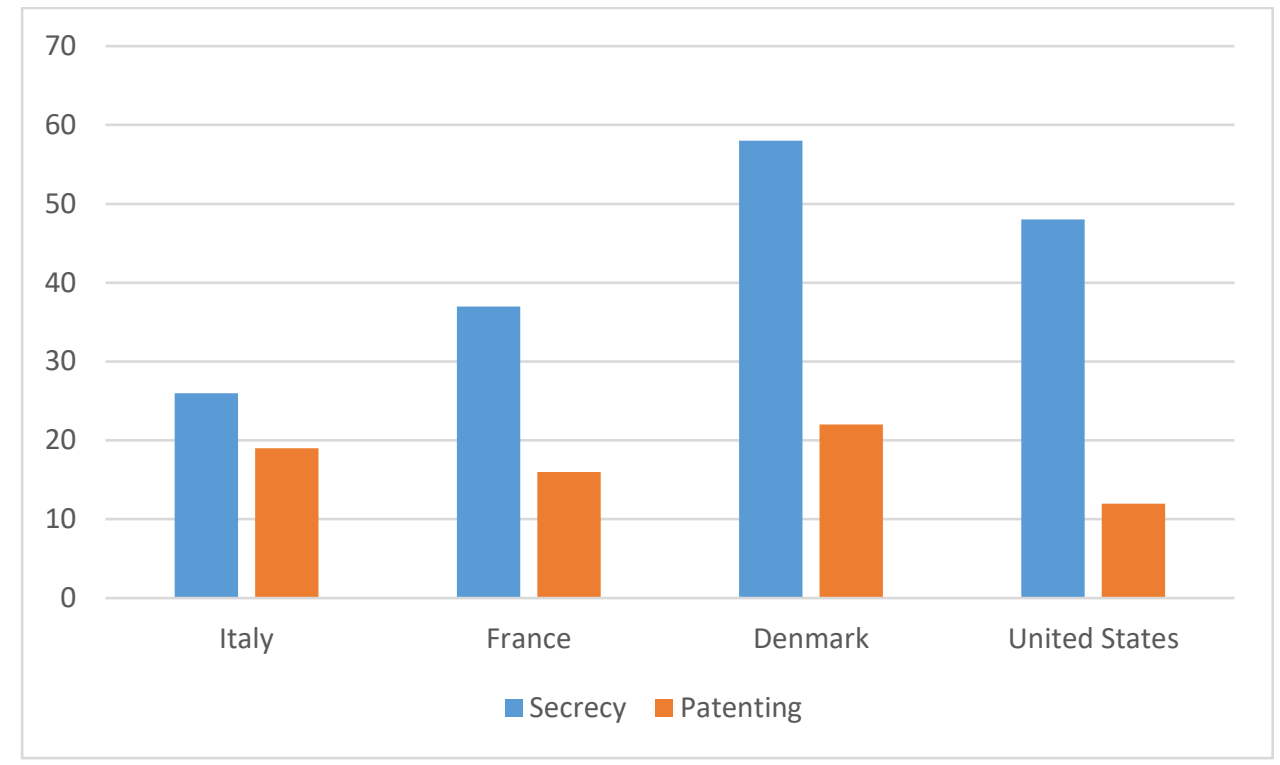

Figure 2: Degree to which Secrecy is used relative to patents. (Y-axis is calculated by subtracting the average Secrecy from average Patenting, both are scales of 1 to 4 )

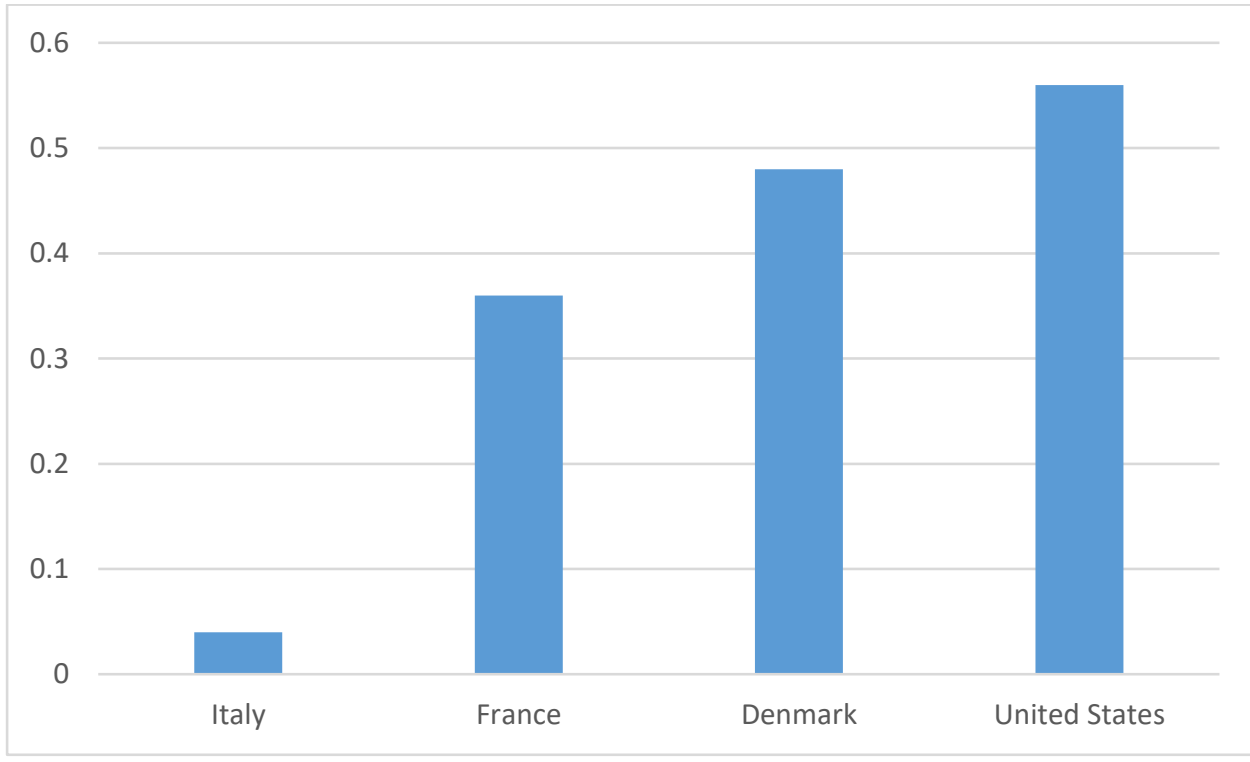


Figure 3: Moderator effect of SMEs' proactive orientation. (Y-axis indicates the Patenting/(Patenting +Secrecy) variable)

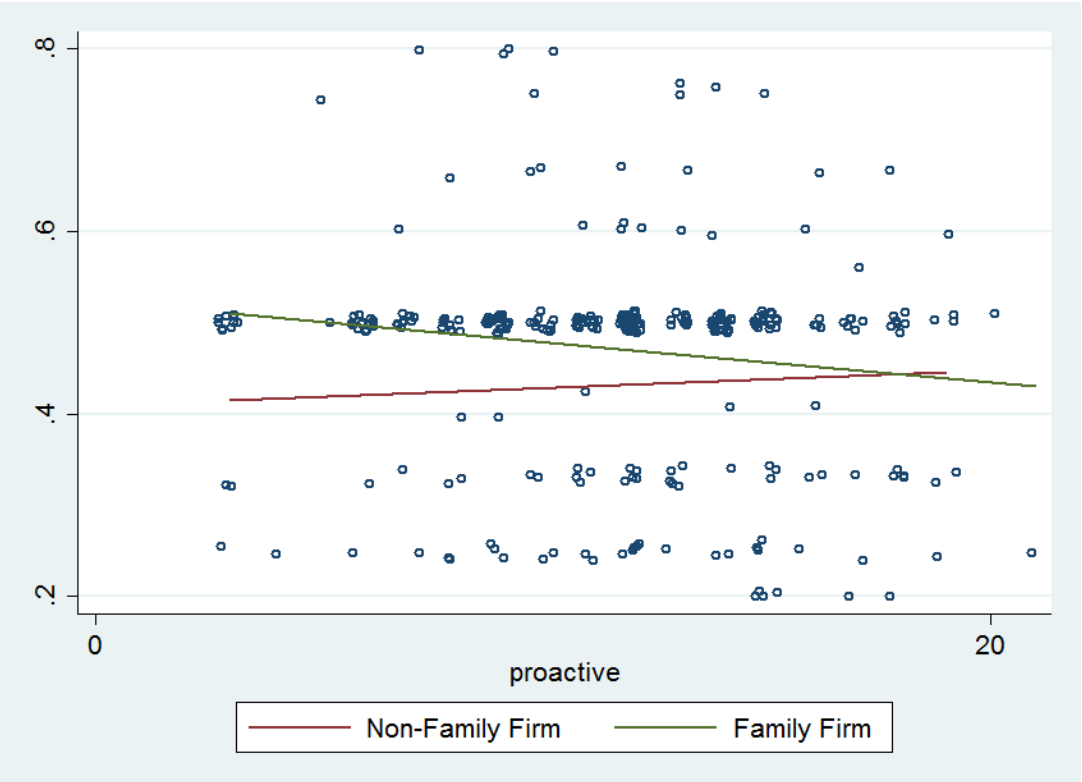

